\title{
Flavonoid 8-O-Glucuronides from the Aerial Parts of Malva verticillata and Their Recovery Effects on Alloxan-Induced Pancreatic Islets in Zebrafish
}

\author{
Jung-Hwan Ko ${ }^{\mathbb{D}}$, Youn Hee Nam, Sun-Woo Joo, Hyoung-Geun Kim, Yeong-Geun Lee, \\ Tong Ho Kang and Nam-In Baek* (iD
}

Graduate School of Biotechnology \& Department of Oriental Medicine Biotechnology, Kyung-Hee University, Yongin 17104, Korea; hwann92@naver.com (J.-H.K.); 01030084217@hanmail.net (Y.H.N.); woojoosun88@naver.com (S.-W.J.); zwang05@naver.com (H.-G.K.); lyg629@nate.com (Y.-G.L.); panjae@khu.ac.kr (T.H.K.)

* Correspondence: nibaek@khu.ac.kr; Tel.: +82-312-012-610; Fax: +82-312-012-157

Academic Editor: Isabel C. F. R. Ferreira

Received: 20 February 2018; Accepted: 4 April 2018; Published: 4 April 2018

\begin{abstract}
Malva verticillata (Cluster mallow), a leafy vegetable that has been popular in East Asia for a long time, has also been used in herbal teas and medicines. The aqueous fraction of the aerial parts of Malva verticillata, exhibiting a very high quantity of flavonoids compared to the EtOAc and $n$-BuOH fractions, exhibited significant recovery effects on pancreatic islets damaged by alloxan in zebrafish larvae. Thus, the bioactive components responsible for this anti-diabetic activity were investigated. A new flavonoid glucuronide (1) and five known flavonoids were isolated from the aqueous fraction. Based on several spectroscopic methods, compound 1 was identified to be nortangeretin-8-O- $\beta$-D-glucuronide, and was named malvaflavone A. The A-ring of compound 1 had a 5,6,7,8-tetrahydroxy moiety, which rarely occurs in plant systems. Also 8-O-glucuronide attached to the flavonoid moiety was rarely occurred in plant system. Compounds 1, 3, 4, and 6 significantly improved the pancreatic islet size in zebrafish at $0.1 \mu \mathrm{M}$, and compounds $\mathbf{1}$ and $\mathbf{6}$ were found to block $\beta$-cell $\mathrm{K}^{+}$channels in experiments with diazoxide. In ABTS, ORAC, and SOD assays, compounds 1-5 exhibited high anti-oxidant activities compared with quercetin and BHA (positive controls), indicating that the 8-O-glucuronide attached to the flavonoid moiety is a key structure for the expression of anti-oxidant activity. This is the first report of the isolation of compounds 1-6 from M. verticillata as well evaluated for anti-diabetic and anti-oxidant ativities.
\end{abstract}

Keywords: Malva verticillata; malvaflavone A; flavonoid 8-O-glucuronide; zebrafish; anti-diabetes; anti-oxidant

\section{Introduction}

Diabetes is characterized by variations in the metabolism of carbohydrates, proteins and fats. It results from insulin secretion disorders or reduced insulin sensitivity to blood sugar levels [1]. In diabetic patients and animal models, the pancreatic islet (PI) size and $\beta$-cell number are smaller than normal [2]. Protection or recovery of the PI constitution could be an efficient pharmacological approach for the treatment of diabetes. The most important route of insulin secretion is the release of insulin from islet cells, a process which is regulated by $\mathrm{K}_{\mathrm{ATP}}$ channels and voltage-gated $\mathrm{Ca}^{2+}$ channels $[3,4]$. $\mathrm{K}_{\text {ATP }}$ channels are closed during insulin secretion, but are open when insulin release is inhibited by $\beta$-cell metabolism.

Epidemiological studies have consistently shown that regular consumption of foods such as vegetables is strongly related to a lower risk of developing chronic diseases such as diabetes [5]. 
Recently, consumers increasingly believe that foods contribute directly to their health [6]. Today, foods are intended not only to satisfy hunger and provide necessary nutrients, but also to prevent nutrition-related diseases and improve physical and mental well-being [7]. It is generally accepted that a food can have health-promoting properties that go beyond its traditional nutritional value. Bioactive compounds (Coms) are defined as components of food that influence physiological or cellular activity in the animals or humans that consume them. Recently, much attention has been given to bioactive food components that may be beneficial for the prevention of chronic diseases such as diabetes [8]. A considerable amount of evidence has indicated that increased oxidative damage contributes to the development of chronic diseases such as diabetes, and several epidemiologic studies have demonstrated that the consumption of polyphenol-rich vegetables is associated with a reduced risk of oxidative stress-related diseases $[9,10]$. Hence, there is a need to search for anti-diabetic food components that prevent chronic diseases and also promote health.

Malva verticillata (Cluster mallow), a leafy vegetable that has been popular in East Asia for a long time, has also been used in herbal teas and medicines [11]. Its seeds in particular have been used in traditional Chinese medicinal formulas as diuretic, laxative, and galactopoietic materials [12]. However, reports on the chemical (Chem) constituents and biological activities of the aerial parts of $M$. verticillata were very insufficient. In our preliminary study, the aqueous fraction $(\mathrm{Fr})$ of the aerial parts of M. verticillata, exhibiting very high quantity of flavonoids comparing to the ethyl acetate (EtOAc) and $n$-butanol $(n-\mathrm{BuOH})$ Frs $[13,14]$. The TLC experiment exhibited the major components of the aqueous Fr of M. verticillata to be oligosaccharides and flavonoids. Some literature has reported that oligosaccharides have significant anti-diabetic activity, showing a hypoglycaemic effect [15], increasing $\beta$-cell function and insulin levels [16], inhibiting $\alpha$-glucosidase activity [17], and promoting peripheral tissue utilization of glucose [18]. However, it is relatively difficult to prepare the oligosaccharide Frs. Flavonoids are a group of naturally occurring polyphenolic Coms present in various fruits and vegetables, and are constituents of a number of effective traditional remedies [19]. To date, a considerable number of flavonoids have been revealed to have anti-oxidant and therapeutic effects in chronic diseases in human populations [20-22]. Some studies have indicated that dietary flavonoids reduce the risk of type 2 diabetes [23-25].

Therefore, in this study, flavonoids with anti-diabetic activity were isolated and identified from the aqueous Fr of the aerial parts of M. verticillata. Six flavonoids were isolated, identified, and investigated for their recovery effects on alloxan (AX)-induced PI damage in zebrafish. The recovery effects of certain Coms were found to be derived from the closing of $\mathrm{K}_{\mathrm{ATP}}$ channels in PIs. The anti-oxidant potential of these flavonoids was measured with DPPH, ABTS, ORAC radical scavenging (RS), and superoxide dismutase (SOD) assays.

\section{Results and Discussion}

Repeated column chromatography for the aqueous Frs of the aerial parts of M. verticillata resulted in the isolation of one new flavone glucuronide (1) and five known Coms (2-6) (Figure 1). Through spectroscopy data analyses such as IR, NMR, and ESI-QTof-MS, and through comparison of the data with those in the literature, these Coms were identified as nortangeretin-8-O- $\beta$-D-glucuronopyranoside (1), isoscutellarein $8-O-\beta$-D-glucuronopyranoside (2) [26], hypolaetin 8-O- $\beta$-D-glucuronopyranoside (3) [26], herbacetin 8-O- $\beta$-D-glucuronopyranoside (4) [27], herbacetin 3-O- $\beta$-D-glucopyranosyl-8-O- $\beta$-D-glucuronopyranoside (5) [28], and isoscutellarein 7-O- $\beta$-D-glucopyranoside (6) [29]. Coms 4 and $\mathbf{6}$ have never been found in the family of Malvaceae, and coms 1-6 were isolated for the first time from the aerial parts of $M$. verticillata in this study. 
<smiles></smiles><smiles>O=c1cc(-c2ccc(O)cc2)oc2c(O)c(O[C@@H]3OC(CO)C[C@@H](O)[C@H](O)C3O)cc(O)c12</smiles>

$$
\begin{aligned}
& 1: R_{1}=O H \\
& 2: R_{1}=H \\
& 3: R_{1}=H \\
& 4: R_{1}=H \\
& 5: R_{1}=H
\end{aligned}
$$

$$
\begin{aligned}
& R_{2}=H \\
& R_{2}=H \\
& R_{2}=O H \\
& R_{2}=H \\
& R_{2}=H
\end{aligned}
$$$$
\mathbf{R}_{3}=\mathbf{H}
$$$$
\mathbf{R}_{3}=\mathbf{H}
$$$$
\mathbf{R}_{3}=\mathbf{H}
$$$$
\mathrm{R}_{3}=\mathrm{OH}
$$

Figure 1. Chemical structures of flavonoids 1-6 isolated from the aerial parts of Malva verticillata.

Com 1, a yellow amorphous powder (pyridine- $d_{5}$ and $\mathrm{D}_{2} \mathrm{O}$ ), exhibited UV absorption characteristics and a pale yellow color in TLC when sprayed with $10 \% \mathrm{H}_{2} \mathrm{SO}_{4}$ and heated. The molecular weight was determined to be 478 from the molecular ion peak $m / z 479.0828[\mathrm{M}+\mathrm{H}]^{+}$ (calculated for $\mathrm{C}_{21} \mathrm{H}_{19} \mathrm{O}_{13}$ 479.0826) in the positive ESI-QTof-MS. The IR spectrum suggested the presence of a hydroxyl group $\left(3386 \mathrm{~cm}^{-1}\right)$, a carbonyl group $\left(1630 \mathrm{~cm}^{-1}\right)$, a conjugated carbonyl group $\left(1617 \mathrm{~cm}^{-1}\right)$, and an aromatic double bond $\left(1580 \mathrm{~cm}^{-1}\right)$. The ${ }^{1} \mathrm{H}-\mathrm{NMR}$ spectrum contained four olefin methine proton signals $\left(\delta_{\mathrm{H}} 8.25,2 \mathrm{H}, \mathrm{d}, J=7.6, \mathrm{H}-2^{\prime}, 6^{\prime} ; \delta_{\mathrm{H}} 7.35,2 \mathrm{H}, \mathrm{d}, J=7.6, \mathrm{H}-3^{\prime}, 5^{\prime}\right)$, which were attributed to a paradisubstituted benzene ring $\mathrm{B}$, and one olefin methine proton signal $\left(\delta_{\mathrm{H}} 6.57,1 \mathrm{H}, \mathrm{s}, \mathrm{H}-3\right)$, which was attributed to $\mathrm{H}-3$ of a flavone $\mathrm{C}$-ring. In the oxygen region, one hemiacetal proton signal $\left(\delta_{\mathrm{H}} 5.05,1 \mathrm{H}, \mathrm{d}, J=7.2 \mathrm{~Hz}, \mathrm{H}-1^{\prime \prime}\right)$ and four oxygenated methine proton signals $\left(\delta_{\mathrm{H}} 4.02-4.04, \mathrm{H}-2^{\prime \prime}-4^{\prime \prime} ; 3.82, \mathrm{~d}, J=8.8 \mathrm{~Hz}, \mathrm{H}-5^{\prime \prime}\right)$ were observed as the signals of a hexuronic acid moiety. The above-mentioned ${ }^{1} \mathrm{H}-\mathrm{NMR}$ spectrum indicated that Com 1 was a pentahydroxyflavone glucuronide. The ${ }^{13} \mathrm{C}-\mathrm{NMR}$ spectrum displayed 21 carbon signals, confirming that Com $\mathbf{1}$ was a pentahydroxyflavone with a hexuronic acid. One conjugated ketone carbon signal $\left(\delta_{C} 180.7, C-4\right)$, nine olefin quaternary carbon signals $\left(\delta_{C} 163.0, C-2 ; 161.6, C-4^{\prime} ; 156.0, C-9 ; 148.3, C-5 ; 144.1, C-7 ; 131.2\right.$, C-6; 127.9, C-8; 121.0, C-1'; 100.8, C-10), and five olefin methine carbon signals $\left(\delta_{C} 128.4, C-2^{\prime}, 6^{\prime} ; 115.7\right.$, $\left.\mathrm{C}-3^{\prime}, 5^{\prime} ; 100.5, \mathrm{C}-3\right)$ in the down-field area were observed as the signals of the aglycone. Based on the Chem shift of the hexuronic acid carbon signals, such as a hemiacetal $\left(\delta_{C} 101.1, C-1^{\prime \prime}\right)$, four oxygenated methines $\left(\delta_{C} 78.6, C-3^{\prime \prime} ; \delta_{C} 75.7, C-5^{\prime \prime} ; \delta_{C} 74.7, C-2^{\prime \prime} ; \delta_{C} 71.3, C-4^{\prime \prime}\right)$, and one carboxyl $\delta_{C} 174.0\left(C-6^{\prime \prime}\right)$, the sugar was identified to be a $\beta$-glucuronic acid. From the coupling constant of the anomer proton signal $(J=7.2 \mathrm{~Hz})$, the anomeric hydroxyl group was confirmed to be in the $\beta$-position. In the gradient heteronuclear multiple-bond connectivity (gHMBC) spectrum, the anomeric proton signal $\left(\delta_{\mathrm{H}} 5.05\right.$, $\left.\mathrm{H}-1^{\prime \prime}\right)$ exhibited ${ }^{3} J$ correlation with the olefin quaternary carbon signal $\left(\delta_{\mathrm{C}} 127.9, \mathrm{C}-8\right)$, indicating that the $\beta$-D-glucuronopyranose was linked to C- 8 of the pentahydroxyflavone. Therefore, the Chem structure of Com 1 was determined to be nortangeretin- $8-O-\beta-D-$ glucuronide, and this Com was named malvaflavone A. The A-ring of malvaflavone A (1) contained 5,6,7,8-tetrahydroxy benzene, which rarely occurs in plant systems.

To evaluate the toxicity of the EtOAc, $n-\mathrm{BuOH}$, and aqueous Frs on zebrafish embryos, the survival rate related to EtOAc, $n$ - $\mathrm{BuOH}$, and aqueous Frs was investigated in zebrafish and $\mathrm{LC}_{50}$ value was calculated. Zebrafish were treated with EtOAc, $n-\mathrm{BuOH}$, and aqueous Frs at ten different concentrations. The $\mathrm{LC}_{50}$ values of EtOAc, $n-\mathrm{BuOH}$, and aqueous Frs were 91.5, 270.9 and $401.1 \mu \mathrm{g} / \mathrm{mL}$, respectively (Figure 2). 


\section{$\mathrm{LC}_{50}$}

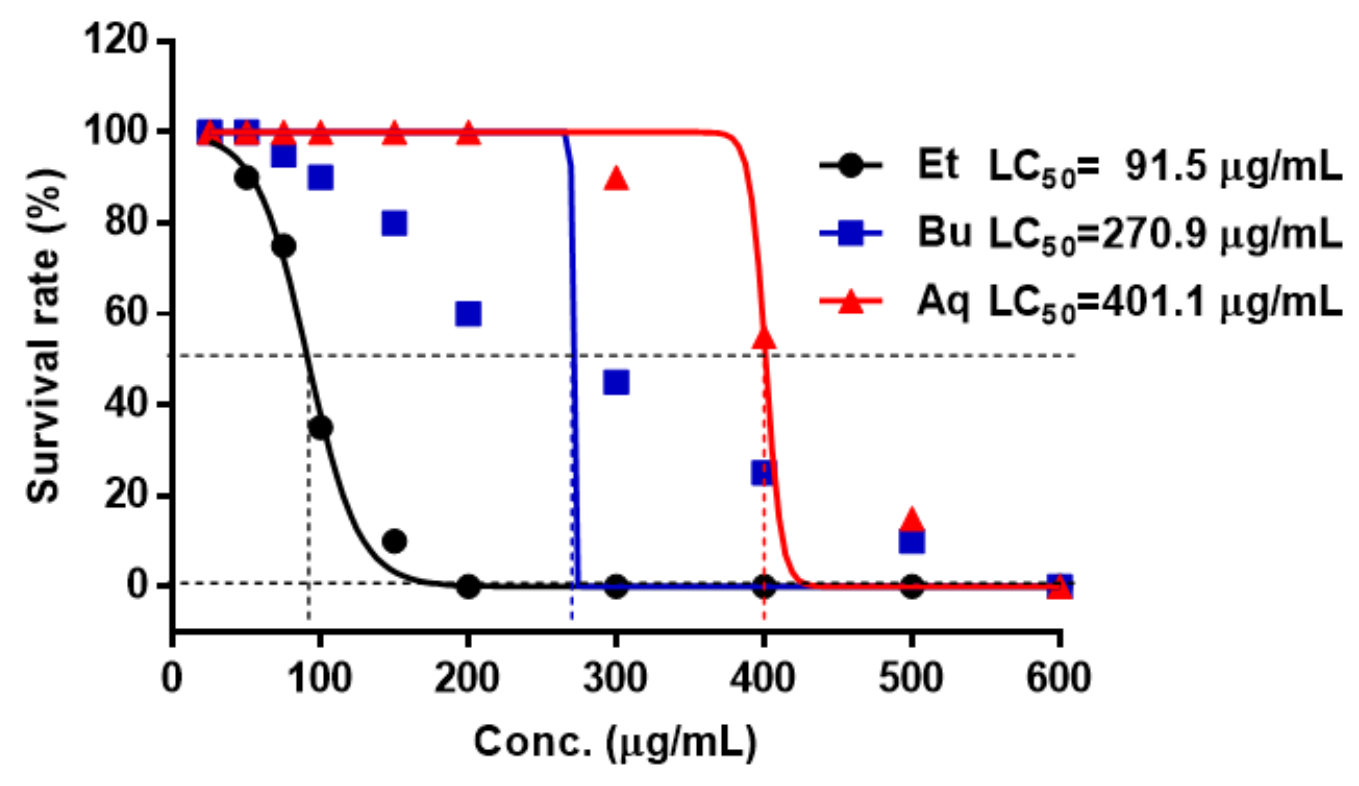

Figure 2. $\mathrm{LC}_{50}$ of zebrafish embryos exposed to EtOAc, $n$-BuOH, and aqueous Frs for $96 \mathrm{~h}$. The $\mathrm{LC}_{50}$ of Et was $91.5 \mu \mathrm{g} / \mathrm{mL}$. The $\mathrm{LC}_{50}$ of Bu and Aq were $270.9 \mu \mathrm{g} / \mathrm{mL}$ and $401.1 \mu \mathrm{g} / \mathrm{mL}$, respectively. NOR: normal group, Et: EtOAc fraction, $\mathrm{Bu}: n-\mathrm{BuOH}$ fraction, Aq: aqueous fraction.

The isolated Coms 1-6 were then evaluated for their recovery effects on AX-induced PI damage in zebrafish larvae. AX is a well-known diabetogenic agent that causes a reduction of insulin release through a $\beta$-cell mass decrease. In addition, AX has already been proven in a zebrafish model in previous studies. The PI size $\left(\mu \mathrm{m}^{2}\right)$ average in normal zebrafish was $1720 \pm 300 \mu \mathrm{m}^{2}$; furthermore, in AX- and glimepiride (GLM)-treated zebrafish, the average was $950 \pm 200 \mu \mathrm{m}^{2}$ and $1680 \pm 220 \mu^{2}$, respectively. PI size was $40.2 \%$ lower $(p<0.0001)$ in the AX treatment group than in the normal group (Figure 3). According to this model, after the exposure to AX, an enhanced recovery from that damage could be observed after treating the zebrafish with some Coms or extracts, the GLM is used as a positive control, since it is a well-known antidiabetic drug, and like the AX, has also been proven in the zebrafish model [30,31]. GLM was used as a positive control, as it promotes insulin secretion by closing the $\mathrm{K}_{\text {ATP }}$ channel [32]. Additionally, glucose uptake was assessed in the zebrafish model with 2-[N-(7-nitrobenz-2-oxa-1,3-diazol-4-yl)amino]-2-deoxyglucose (2-NBDG), which is a fluorescent dye derived from glucose, modified with an amino group at the C-2 position [33]. In diabetes studies, 2-NBDG is widely used to measure the ability of cells to absorb glucose [34]. Both the PI size and fluorescence intensity were significantly greater in the GLM-treated group than in the AX-treated group. When Coms 1-6 were added to AX-treated zebrafish larvae, Coms 1, 3, 4, and 6 significantly increased the size of the injured PIs, by $49.4 \%(p=0.0072), 46.8 \%(p=0.0028), 62.4 \%$ $(p<0.0001)$, and $54.9 \%(p=0.0088)$, respectively, compared with AX alone (Figure 3D,E). Some reports have mentioned that anti-diabetes activity was influenced in compliance with the number of hydroxyl groups in an aromatic moiety. Because Coms 1, 3, and 4 included one more hydroxyl group in the structure than Com 2, the former three showed higher activity than the latter. Additionally, Com 5 has two sugar moieties in the structure, which induces the decease of the anti-diabetes activity $[35,36]$. Furthermore, flavonoids with 7,8-dihydroxy moiety, such as Com 6, have been reported to improve blood insulin concentration, to lower blood glucose level, and to increase insulin sensitivity in tissues such as liver, fat, and muscles [37].

As shown in Figure 3B,D, the aqueous Fr showed higher recovery effect on the AX-induced pancreatic islets in zebrafish than those of each components. The preliminary TLC experiment 
indicated the aqueous Fr contained high amount of oligosaccharides, in addition to flavonoids. The oligosaccharides have been reported to have significant anti-diabetic activity in many previous works [15-18].

A

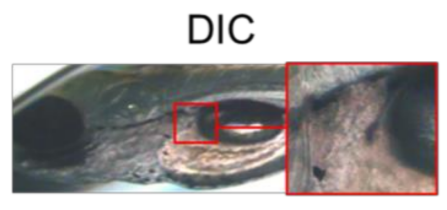

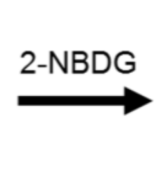

\section{B}

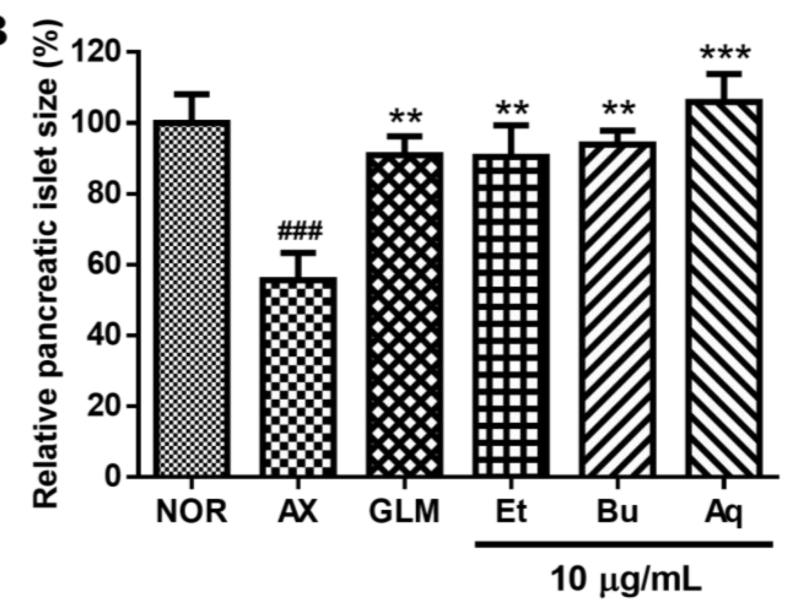

D

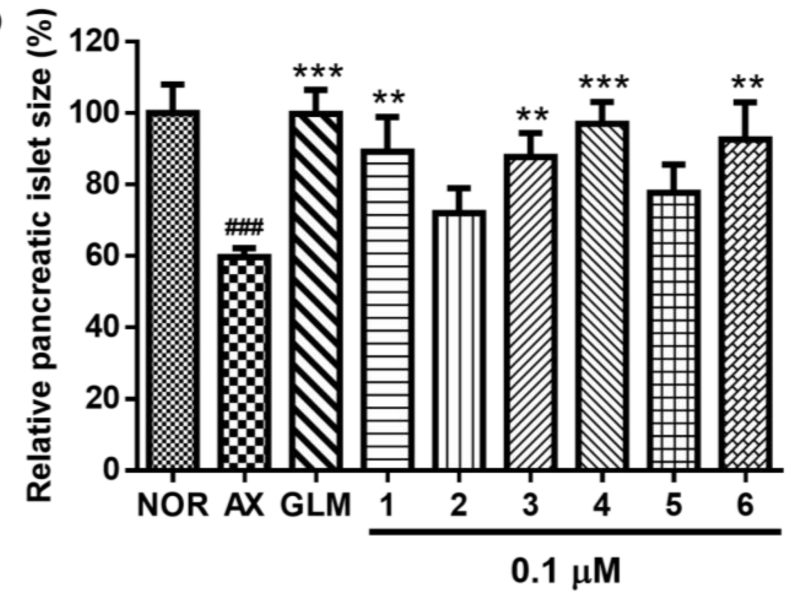

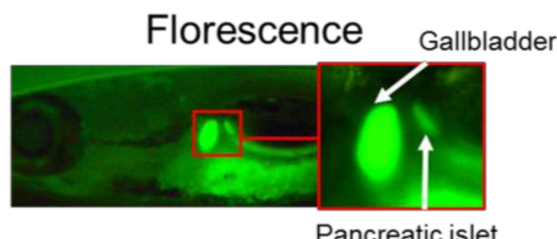

C
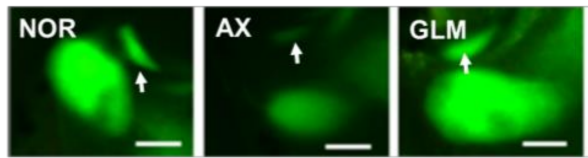

Et

$\uparrow$
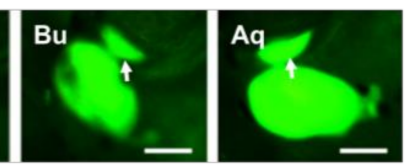

$\mathbf{E}$
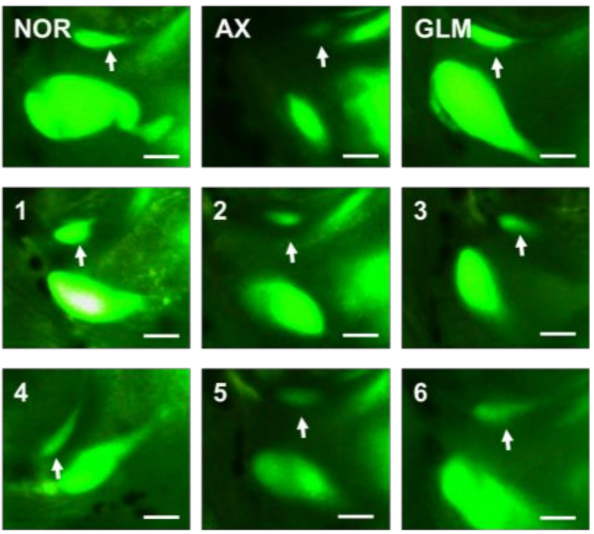

Figure 3. Changes in pancreatic islet (PI) area and fluorescence intensity caused by 2-NBDG. (A) The PI sizes of wild-type zebrafish and zebrafish larvae at 5 days post-fertilization (dpf) were evaluated by differential interference contrast (DIC) and fluorescence microscopy. (B) Changes in PI size caused in each fraction were analyzed with Focus Lite software. NOR: normal group, AX: alloxan-induced group, GLM: glimepiride, Et: EtOAc fraction, $\mathrm{Bu}$ : $n$-BuOH fraction, Aq: aqueous fraction. (\#\#\# $p<0.001$; compared to NOR), $\left({ }^{* *} p<0.01,{ }^{* *} p<0.001\right.$; compared to AX). (C) Fluorescent microscopic images of PIs treated with each fraction following treatment with 2-NBDG at $10 \mu \mathrm{g} / \mathrm{mL}$. (D) Changes in PI size caused by compounds 1-6, analyzed with Focus Lite software. (E) Fluorescent microscopic images of PIs treated with compounds 1-6 following treatment with 2-NBDG at $0.1 \mu \mathrm{M}$.

Due to their effects on PI size, Coms 1, 3, 4, and 6 were investigated for their ability to alter insulin secretion by modulating $\mathrm{K}_{\mathrm{ATP}}$ channels. Diazoxide (DZ) was used as a $\mathrm{K}_{\mathrm{ATP}}$ channel opener, and pancreatic $\beta$-cell $\mathrm{K}_{\mathrm{ATP}}$ channel stimulation activity was measured. The size of the PIs was significantly smaller $(23.5 \%, p=0.0105)$ in the DZ-treated normal group than in the normal group without DZ. The PI size in the AX group did not change significantly after the zebrafish 
larvae were treated with $25 \mu \mathrm{M}$ DZ. The PI sizes in AX-induced zebrafish larvae treated with $0.1 \mu \mathrm{M}$ GLM were significantly reduced following cotreatment with $25 \mu \mathrm{M} \mathrm{DZ}(41.1 \%, p=0.0001)$. Similarly, in AX-induced zebrafish larvae treated with Coms $\mathbf{1}$ and 6, the PI sizes were significantly reduced following cotreatment with $25 \mu \mathrm{M} \mathrm{DZ}(32.2 \%, p=0.0027$ and $29.7 \%, p=0.0182$, respectively). However, in AX-induced zebrafish larvae treated with Coms 3 and 4, the PI sizes were almost the same after cotreatment with $25 \mu \mathrm{M}$ DZ, indicating that Coms 3 and 4 had no relationship with $\mathrm{K}_{\text {ATP }}$ channels (Figure 4). Thus, Coms 1, 3, 4, and $6(0.1 \mu \mathrm{M})$ exerted significant recovery effects on the size of PIs damaged by AX in zebrafish, and Coms $\mathbf{1}$ and $\mathbf{6}$ were confirmed to influence $\mathrm{K}_{\mathrm{ATP}}$ channels in DZ experiments. According to this study, the natural Coms of M. verticillata may exert their action by closing the $\mathrm{K}_{\text {ATP }}$ channels, which is demonstrated by the inhibition of the effect when cotreated with DZ, a well-known $\mathrm{K}_{\mathrm{ATP}}$ channel opener, resulting in an increased insulin secretion and a consequently increased glucose uptake.

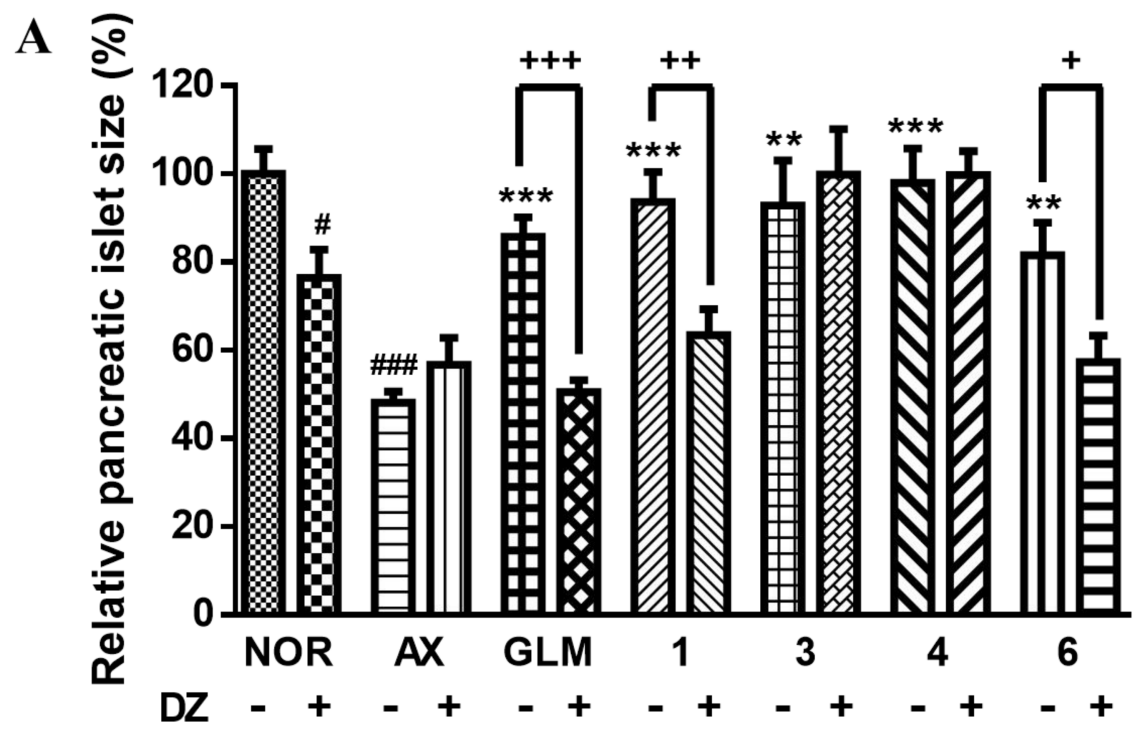

\section{B}
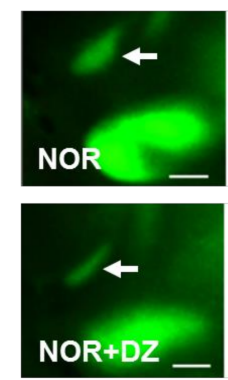
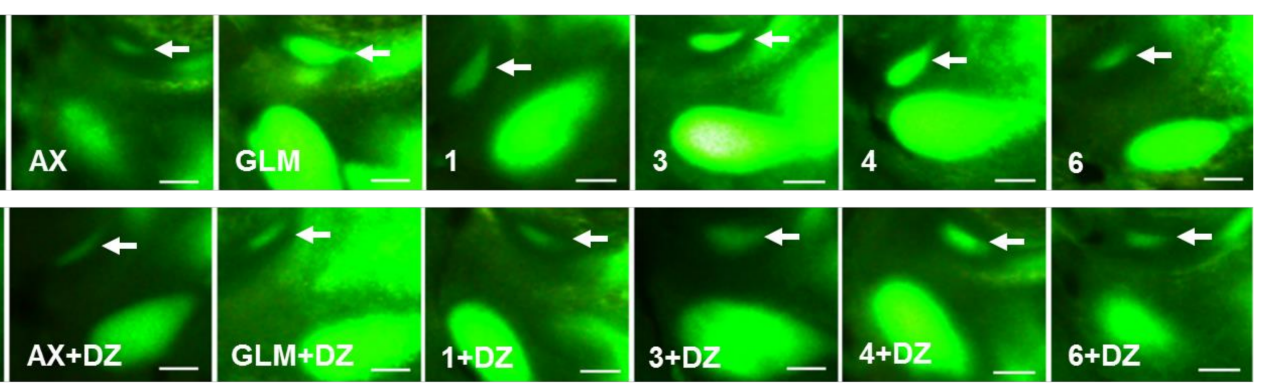

Figure 4. Recovery effects of flavonoids 1, 3, 4, and 6 on zebrafish larvae treated with alloxan (AX) and diazoxide (DZ). Glimepiride (GLM) was used as a positive control. $\left({ }^{\#} p<0.05\right.$, \#\#\# $p<0.001$; compared to NOR), $\left({ }^{* *} p<0.01,{ }^{* * *} p<0.001\right.$; compared to AX), $\left({ }^{+} p<0.05,{ }^{++} p<0.01,{ }^{+++} p<0.001\right)$. (A) Recovery effects of flavonoids 1, 3, 4, and 6 on zebrafish larvae treated with AX and DZ. (B) Fluorescent microscopic images of PIs treated with compounds 1, 3, 4, and $\mathbf{6}$ following treatment with 2-NBDG at $0.1 \mu \mathrm{M}$.

In the DPPH RS assay, Coms 3-5 exhibited activity comparing to positive controls (quercetin and BHA). And Coms 1-6 displayed significant activity, comparing to positive controls in the ABTS RS, oxygen radical absorbance capacity (ORAC), and superoxide dismutase (SOD) assays (Table 1). Coms 1-5 were revealed to have high anti-oxidant activities in the ABTS, ORAC, and SOD assays, indicating that the 8-O-glucuronic acid moiety is a key structure for the expression of anti-oxidant activity. In particular, because Coms 1 and 3 exhibited very high anti-oxidant activity, the 1,2,3-trihydroxy benzene 
moiety in the flavonoid A-ring and the 1,2-dihydroxy benzene moiety in the flavonoid B-ring appear to contribute to anti-oxidant activity. The glucuronic acid moieties in Coms 1-5 may have reduced their solubility in $70 \% \mathrm{MeOH}$, which was used as a solvent for the DPPH assay. Therefore, the DPPH RS activities of Coms 1-5 were not as high as expected. Despite low solubility of Com 3 in $70 \% \mathrm{MeOH}$, B-ring of Com 3 has the 1,2-dihydroxy (catechol) moiety, which is well known to exhibit high radical scavenging activity $[38,39]$. Com 3 showed the highest anti-oxidant activity; on the contrary, Com 6 showed the lowest activity in most assays. As mentioned above, Com 3 has the 1,2-dihydroxy (catechol) moiety. Additionally, among six flavonoid glycosides, Coms 1-5 have the glucuronic acid in the structure, but Com 6 has glucoside.

Table 1. Antioxidant activities of flavonoids 1-6 on DPPH, ABTS, ORAC, and SOD assays.

\begin{tabular}{|c|c|c|c|c|}
\hline Compounds & DPPH EC ${ }_{50}{ }^{a}(\mu \mathrm{M})$ & ABTS EC E0 $_{50}(\mu \mathrm{M})$ & $\begin{array}{c}\text { ORAC ( } \mu \mathrm{mol} \\
\text { TE } / \mu \mathrm{mol})\end{array}$ & SOD EC $E_{50}(\mu \mathrm{M})$ \\
\hline Quercetin & $4.08 \pm 0.36^{b}$ & $1.73 \pm 0.09$ & $7.33 \pm 0.15$ & $0.43 \pm 0.10$ \\
\hline BHA & $8.33 \pm 0.46$ & $4.65 \pm 0.18$ & $2.86 \pm 0.26$ & $0.44 \pm 0.09$ \\
\hline 1 & $>50$ & $2.22 \pm 0.05$ & $14.38 \pm 0.35$ & $0.73 \pm 0.09$ \\
\hline 2 & $>50$ & $3.38 \pm 0.15$ & $8.06 \pm 0.36$ & $1.51 \pm 0.15$ \\
\hline 3 & $5.98 \pm 0.24$ & $1.52 \pm 0.04$ & $12.48 \pm 1.27$ & $0.98 \pm 0.13$ \\
\hline 4 & $31.79 \pm 2.22$ & $4.51 \pm 0.13$ & $6.56 \pm 0.32$ & $1.04 \pm 0.21$ \\
\hline 5 & $33.80 \pm 1.89$ & $4.05 \pm 0.14$ & $6.42 \pm 0.18$ & $0.70 \pm 0.18$ \\
\hline 6 & $>50$ & $21.62 \pm 1.26$ & $3.83 \pm 0.30$ & $1.31 \pm 0.20$ \\
\hline
\end{tabular}

${ }^{\mathrm{a}} \mathrm{EC}_{50}$ is a concentration required to obtain a $50 \%$ antioxidant effect. ${ }^{\mathrm{b}}$ Each result was expressed as mean $\pm \mathrm{SD}$ $(\mu \mathrm{M}$ or $\mu \mathrm{mol} \mathrm{TE} / \mu \mathrm{mol})$ in triplicate studies.

In this study, a new flavonoid glucuronide (1) and five known flavonoids (2-6) were first isolated from the aqueous Fr of the aerial parts of $M$. verticillata and identified. The 5,6,7,8-tetrahydroxy benzene ring in Com 1 was of particular interest, as it rarely occurs in plant systems. Coms 1, 3, 4, and $\mathbf{6}(0.1 \mu \mathrm{M})$ were revealed to restore the PI mass in zebrafish damaged by AX treatment, and Coms $\mathbf{1}$ and $\mathbf{6}$ were found to block $\beta$-cell $\mathrm{K}^{+}$channels in experiments with DZ. Additionally, Coms 1-5 exhibited significant anti-oxidant activity in ABTS, ORAC, and SOD assays, indicating that the 8-O-glucuronide attached to the flavonoid moiety is a key structure for the expression of anti-oxidant activity. Coms $\mathbf{1}$ and $\mathbf{3}$ exhibited especially high RS activities in ABTS and ORAC assays, indicating that the 1,2,3-trihydroxy benzene moiety in the flavonoid A-ring and the 1,2-dihydroxy benzene moiety in the flavonoid B-ring are closely related to anti-oxidant activity (Table 2).

In conclusion, Coms 1-6 were isolated from $M$. verticillata, and their anti-diabetic and antioxidant activities were evaluated for the first time. These results suggest that steady intake of $M$. verticillata could have anti-diabetic and antioxidant effects.

\section{Experimental}

\subsection{Materials}

The aerial parts of M. verticillata were purchased from a commercial farm in Namyangju city, Korea in April 2016. The voucher specimen (KHU20160419) is deposited at the Laboratory of Natural Products Chemistry, Kyung Hee University, Yongin, Korea.

\subsection{Reagents and Instrumentation}

The silica gel $\left(\mathrm{SiO}_{2}\right)$ and octadecyl $\mathrm{SiO}_{2}$ (ODS) resins used for column chromatography (CC) were Kiesel gel 60 (Merck, Darmstadt, Germany) and Lichroprep RP-18 (40-60 $\mu \mathrm{m}$, Merck, Darmstadt, Germany), respectively. Sephadex LH-20 was purchased from Amersham Biosciences (Uppsala, Sweden). Thin layer chromatography (TLC) analysis was carried out with Kiesel gel $60 \mathrm{~F}_{254}$ and RP-18 $\mathrm{F}_{254 S}$ (Merck) TLC plates, and the Coms were detected with a Spectroline Model ENF-240 C/F UV 
lamp (Spectronics Corporation, Westbury, NY, USA) and a $10 \% \mathrm{H}_{2} \mathrm{SO}_{4}$ solution. Nuclear magnetic resonance (NMR) spectra were recorded on a $400 \mathrm{MHz}$ FT-NMR spectrometer (Varian Inova AS-400, Palo Alto, CA, USA). Deuterium solvents were purchased from Merck Co. Ltd and Sigma Aldrich Co. Ltd (St. Louis, MO, USA). IR spectra were obtained on a Perkin Elmer Spectrum One FT-IR spectrometer (Buckinghamshire, England). Quadrupole time-of-flight tandem mass spectrometry (ESI-QTof-MS) spectra were recorded on a Vion IMS QTof Mass Spectrometer (Waters Corporation, Milford, MA, USA). Melting points (Mp) were obtained with a Fisher-John's Melting Point Apparatus (Fisher Scientific, Miami, FL, USA) with a microscope, and the values obtained were uncorrected. Optical rotation was measured on a JASCO P-1010 digital polarimeter (Jasco, Tokyo, Japan). AX and sea salts were purchased from Sigma Chem Co. (St. Louis, MO, USA). GLM was obtained from Cayman Chem Co. (Ann Arbor, MI, USA). 2-NBDG was purchased from Invitrogen (Life Technologies, Grand Island, NY, USA). DZ was purchased Santa Cruz Biotechnology (Dallas, TX, USA). Fluorescence microscopy was performed on an Olympus 1X70 microscope (Tokyo, Japan). For image analysis, Focus Lite (Focus Co., Daejeon, Korea) was used.

\subsection{Isolation of Flavonoids}

Dried aerial parts of $M$. verticillata $(3.1 \mathrm{~kg})$ were extracted with $80 \% \mathrm{MeOH}(54.0 \mathrm{~L} \times 5)$ at room temperature for $24 \mathrm{~h}$. The extracts were filtered through filter paper and evaporated under reduced pressure at $43{ }^{\circ} \mathrm{C}$ to yield $794 \mathrm{~g}$ of extract. The obtained $\mathrm{MeOH}$ extracts were suspended in $\mathrm{H}_{2} \mathrm{O}$ $(2 \mathrm{~L})$ and then successively extracted with EtOAc $(2 \mathrm{~L} \times 4)$ and $n$ - $\mathrm{BuOH}(2 \mathrm{~L} \times 4)$. Each layer was concentrated so that EtOAc (MVE, $80 \mathrm{~g}$ ), $n$ - $\mathrm{BuOH}$ (MVB, $75 \mathrm{~g}$ ), and aqueous (MVW, $637 \mathrm{~g}$ ) Frs could be obtained. The aqueous Fr (MVW, $637 \mathrm{~g})$ was applied to a Diaion HP-20 column $(\varphi 9 \times 30 \mathrm{~cm})$ and eluted with $\mathrm{H}_{2} \mathrm{O}-\mathrm{MeOH}\left(\mathrm{H}_{2} \mathrm{O} \rightarrow 5: 1 \rightarrow 3: 2 \rightarrow 2: 3 \rightarrow 1: 4,7.2 \mathrm{~L}\right.$ of each) to yield nine Frs (MVW-1 to MVW-9). Fr MVW-5 [18.3 g, elution volume/total volume $\left(\mathrm{V}_{\mathrm{e}} / \mathrm{V}_{\mathrm{t}}\right)$ 0.478-0.778] was subjected to ODS CC $(\varphi 5 \times 15 \mathrm{~cm})$ and eluted with $\mathrm{MeOH}-\mathrm{H}_{2} \mathrm{O}(1: 4,2.6 \mathrm{~L})$ to yield nine Frs (MVW-5-1 to MVW-5-9). Fr MVW-5-4 [1.4 g, $\mathrm{V}_{\mathrm{e}} / \mathrm{V}_{\mathrm{t}}$ 0.167-0.189] was subjected to $\mathrm{SiO}_{2} \mathrm{CC}(\varphi 4.5 \times 15 \mathrm{~cm})$ and eluted with $\mathrm{CHCl}_{3}-\mathrm{MeOH}-\mathrm{H}_{2} \mathrm{O}$ (9:3:1 $\rightarrow 6: 4: 1,4.4 \mathrm{~L}$ of both) to yield $17 \mathrm{Frs}$ (MVW-5-4-1 to MVW-5-4-17). Fr MVW-5-4-13 (444.1 mg, $\mathrm{V}_{\mathrm{e}} / \mathrm{V}_{\mathrm{t}}$ 0.520-0.627) was subjected to ODS CC $(\varphi 3 \times 5 \mathrm{~cm})$ and eluted with acetone- $\mathrm{H}_{2} \mathrm{O}$ (1:4, 1.5 L) to yield 7 Frs (MVW-5-4-13-1 to MVW-5-4-13-7). Fr MVW-5-4-13-3 [116.1 mg, $\mathrm{V}_{\mathrm{e}} / \mathrm{V}_{\mathrm{t}}$ 0.273-0.358] was subjected to $\mathrm{SiO}_{2} \mathrm{CC}(\varphi 2.5 \times 5 \mathrm{~cm})$ and eluted with $\mathrm{CHCl}_{3}-\mathrm{MeOH}_{-} \mathrm{H}_{2} \mathrm{O}$ (6:4:1, 3.2 L) to yield 6 Frs (MVW-5-4-13-3-1 to MVW-5-4-13-3-6), which included two purified Coms, 4 and 5 [4, MVW-5-4-13-3-2, $24.2 \mathrm{mg}, \mathrm{V}_{\mathrm{e}} / \mathrm{V}_{\mathrm{t}}$ 0.200-0.369, TLC (Kiesel gel $\left.60 \mathrm{~F}_{254}\right) \mathrm{R}_{\mathrm{f}} 0.51$, $\mathrm{CHCl}_{3}-\mathrm{MeOH}-\mathrm{H}_{2} \mathrm{O}$ (6:4:1), TLC (RP-18 $\left.\mathrm{F}_{254 \mathrm{~S}}\right) \mathrm{R}_{\mathrm{f}}$ 0.91, acetone- $\mathrm{H}_{2} \mathrm{O}(2: 3) ;$ 5, MVW-5-4-13-3-4, $20.5 \mathrm{mg}$, $\mathrm{V}_{\mathrm{e}} / \mathrm{V}_{\mathrm{t}}$ 0.494-0.756, TLC (Kiesel gel $60 \mathrm{~F}_{254}$ ) $\mathrm{R}_{\mathrm{f}} 0.25, \mathrm{CHCl}_{3}-\mathrm{MeOH}-\mathrm{H}_{2} \mathrm{O}(6: 4: 1)$, TLC (RP-18 $\mathrm{F}_{254 \mathrm{~S}}$ ) $\mathrm{R}_{\mathrm{f}}$ 0.80, acetone- $\left.\mathrm{H}_{2} \mathrm{O}(2: 3)\right]$. Fr MVW-5-4-13-4 [107.9 mg, $\mathrm{V}_{\mathrm{e}} / \mathrm{V}_{\mathrm{t}}$ 0.359-0.552] was subjected to $\mathrm{SiO}_{2} \mathrm{CC}(\varphi$ $2.5 \times 15 \mathrm{~cm}$ ) and eluted with EtOAc- $n-\mathrm{BuOH}-\mathrm{H}_{2} \mathrm{O}(4: 3: 1,2.2 \mathrm{~L})$ to yield nine Frs (MVW-5-4-13-4-1 to MVW-5-4-13-4-9), which included two purified Coms, 1 and 6 [1, MVW-5-4-13-4-6, $16.4 \mathrm{mg}, \mathrm{V}_{\mathrm{e}} / \mathrm{V}_{\mathrm{t}}$ 0.306-0.404, TLC (Kiesel gel $60 \mathrm{~F}_{254}$ ) $\mathrm{R}_{\mathrm{f}}$ 0.90, EtOAc-isopropanol- $\mathrm{H}_{2} \mathrm{O}$ (1:4:1), TLC (RP-18 $\mathrm{F}_{254 \mathrm{~S}}$ ) $\mathrm{R}_{\mathrm{f}}$ 0.68, acetone- $\mathrm{H}_{2} \mathrm{O}(1: 2) ; 6$, MVW-5-4-13-4-8, $28.2 \mathrm{mg}, \mathrm{V}_{\mathrm{e}} / \mathrm{V}_{\mathrm{t}}$ 0.557-1.000, TLC (Kiesel gel $60 \mathrm{~F}_{254}$ ) $\mathrm{R}_{\mathrm{f}}$ 0.72, EtOAc-isopropanol- $\mathrm{H}_{2} \mathrm{O}(1: 4: 1)$, TLC (RP-18 $\left.\mathrm{F}_{254 \mathrm{~S}}\right) \mathrm{R}_{\mathrm{f}}$ 0.88, acetone- $\mathrm{H}_{2} \mathrm{O}$ (1:2)]. Fr MVW-5-4-13-5 [86.0 mg, $\left.\mathrm{V}_{\mathrm{e}} / \mathrm{V}_{\mathrm{t}} 0.553-0.670\right]$ was subjected to ODS CC $(\varphi 2.0 \times 7 \mathrm{~cm})$ and eluted with MeOH- $\mathrm{H}_{2} \mathrm{O}(1: 3$, 2.9 L) to yield four Frs (MVW-5-4-13-5-1 to MVW-5-4-13-5-4), which included two purified Coms, 3 and 2 [3, MVW-5-4-13-5-1, $18.0 \mathrm{mg}, \mathrm{V}_{\mathrm{e}} / \mathrm{V}_{\mathrm{t}}$ 0.001-0.027, TLC (Kiesel gel $60 \mathrm{~F}_{254}$ ) $\mathrm{R}_{\mathrm{f}}$ 0.50, $\mathrm{CHCl}_{3}-\mathrm{MeOH}_{\mathrm{H}} \mathrm{O}$ (6:4:1), TLC (RP-18 $\left.\mathrm{F}_{254 \mathrm{~S}}\right) \mathrm{R}_{\mathrm{f}}$ 0.68, acetone- $\mathrm{H}_{2} \mathrm{O}$ (2:3); 2, MVW-5-4-13-5-3, $31.2 \mathrm{mg}, \mathrm{V}_{\mathrm{e}} / \mathrm{V}_{\mathrm{t}}$ 0.537-1.000, TLC (Kiesel gel $\left.60 \mathrm{~F}_{254}\right) \mathrm{R}_{\mathrm{f}} 0.50, \mathrm{CHCl}_{3}-\mathrm{MeOH}-\mathrm{H}_{2} \mathrm{O}(6: 4: 1)$, TLC (RP-18 $\left.\mathrm{F}_{254 \mathrm{~S}}\right) \mathrm{R}_{\mathrm{f}} 0.62$, acetone- $\mathrm{H}_{2} \mathrm{O}$ (2:3)].

Malvaflavone A (MVW-5-4-13-4-6, 1), yellow amorphous powder; $[\alpha]_{\mathrm{D}}-31.9^{\circ}(c 0.10,50 \% \mathrm{MeOH})$; $\mathrm{Mp}$ decomposed $>300{ }^{\circ} \mathrm{C}$; IR $(\mathrm{KBr}, v) 3386,1630,1617,1580 \mathrm{~cm}^{-1}$; positive ESI-QTof-MS $\mathrm{m} / z 479.0828$ $[\mathrm{M}+\mathrm{H}]^{+}$(calculated for $\left.\mathrm{C}_{21} \mathrm{H}_{19} \mathrm{O}_{13}: 479.0826\right) ;{ }^{1} \mathrm{H}-\mathrm{NMR}\left(400 \mathrm{MHz}\right.$, pyridine- $d_{5}$ and $\left.\mathrm{D}_{2} \mathrm{O}, \delta_{\mathrm{H}}\right)$ and ${ }^{13} \mathrm{C}-\mathrm{NMR}\left(100 \mathrm{MHz}\right.$, pyridine- $d_{5}$ and $\left.\mathrm{D}_{2} \mathrm{O}, \delta_{\mathrm{C}}\right)$; see Table 2 . 
Table 2. ${ }^{1} \mathrm{H}(400 \mathrm{MHz})$ and ${ }^{13} \mathrm{C}(100 \mathrm{MHz}) \mathrm{NMR}$ data for compound $\mathbf{1}$ (pyridine- $d_{5}$ and $\mathrm{D}_{2} \mathrm{O}(5: 5), \delta$ ppm, coupling patterns, $J$ in $\mathrm{Hz})^{\text {a }}$ (see Supplementary Materials).

\begin{tabular}{lll}
\hline \multirow{2}{*}{ Carbon No. } & \multicolumn{2}{c}{$\mathbf{1}$} \\
\cline { 2 - 3 } & $\boldsymbol{\delta}_{\mathbf{c}}$ & $\boldsymbol{\delta}_{\mathbf{H}}$ \\
\hline Aglycon & & \\
2 & 163.0 & - \\
3 & 100.5 & $6.57(\mathrm{~s})$ \\
4 & 180.7 & - \\
5 & 148.3 & - \\
6 & 131.2 & - \\
7 & 144.1 & - \\
8 & 127.9 & - \\
9 & 156.0 & - \\
10 & 100.8 & - \\
$1^{\prime}$ & 121.0 & - \\
$2^{\prime}, 6^{\prime}$ & 128.4 & $8.25(\mathrm{~d}, 7.6)$ \\
$3^{\prime}, 5^{\prime}$ & 115.7 & $7.35(\mathrm{~d}, 7.6)$ \\
$4^{\prime}$ & 161.6 & - \\
Sugar moiety & & \\
$1^{\prime \prime}$ & 101.1 & $5.05(\mathrm{~d}, 7.2)$ \\
$2^{\prime \prime}$ & 74.7 & $4.02-4.04 \mathrm{~b}$ \\
$3^{\prime \prime}$ & 78.6 & $4.02-4.04 \mathrm{~b}$ \\
$4^{\prime \prime}$ & 71.3 & $4.20(\mathrm{~m})$ \\
$5^{\prime \prime}$ & 75.7 & $3.82(\mathrm{~d}, 8.8)$ \\
$6^{\prime \prime}$ & 174.0 & - \\
\hline positions were assigned by HSQC and HMBC experiments. ${ }^{\mathrm{b}}$ This signals were overlapped.
\end{tabular}

Isoscutellarein 8-O- $\beta$-D-glucuronopyranoside (MVW-5-4-13-5-3, 2), yellow amorphous powder; $[\alpha]_{\mathrm{D}}-11.2^{\circ}$ (c 0.10, 50\% MeOH); Mp decomposed >300 ${ }^{\circ} \mathrm{C}$; IR (KBr, v) 3384, 1632, 1619, $1582 \mathrm{~cm}^{-1}$; positive ESI-QTof-MS $m / z 463[\mathrm{M}+\mathrm{H}]^{+} ;{ }^{1} \mathrm{H}$-NMR $\left(400 \mathrm{MHz}\right.$, pyridine- $d_{5}$ and $\left.\mathrm{D}_{2} \mathrm{O}, \delta_{\mathrm{H}}\right) 8.40(2 \mathrm{H}, \mathrm{d}$, $\left.J=8.0, \mathrm{H}-2^{\prime}, 6^{\prime}\right), 7.48\left(2 \mathrm{H}, \mathrm{d}, J=8.0, \mathrm{H}-3^{\prime}, 5^{\prime}\right), 6.76(1 \mathrm{H}, \mathrm{s}, \mathrm{H}-3), 6.56(1 \mathrm{H}, \mathrm{s}, \mathrm{H}-6), 5.07\left(1 \mathrm{H}, \mathrm{d}, J=7.6, \mathrm{H}-1^{\prime \prime}\right)$, $4.35\left(1 \mathrm{H}, \mathrm{m}, \mathrm{H}-4^{\prime \prime}\right), 4.31\left(1 \mathrm{H}\right.$, overlapped, $\left.\mathrm{H}-2^{\prime \prime}, 3^{\prime \prime}\right), 4.19\left(1 \mathrm{H}, \mathrm{d}, J=8.8, \mathrm{H}-5^{\prime \prime}\right) ;{ }^{13} \mathrm{C}-\mathrm{NMR}(100 \mathrm{MHz}$, pyridine- $d_{5}$ and $\left.\mathrm{D}_{2} \mathrm{O}, \delta_{\mathrm{C}}\right) 181.4(\mathrm{C}-4), 173.8\left(\mathrm{C}-6^{\prime \prime}\right), 163.8(\mathrm{C}-2), 160.8\left(\mathrm{C}-4^{\prime}\right), 156.5(\mathrm{C}-5,7), 148.8(\mathrm{C}-9)$, $128.5\left(\mathrm{C}-2^{\prime}, 6^{\prime}\right), 125.3(\mathrm{C}-8), 120.7\left(\mathrm{C}-1^{\prime}\right), 115.7\left(\mathrm{C}-3^{\prime}, 5^{\prime}\right), 106.1\left(\mathrm{C}-1^{\prime \prime}\right), 102.6(\mathrm{C}-10), 101.6(\mathrm{C}-3), 99.4(\mathrm{C}-6)$, $76.7\left(\mathrm{C}-3^{\prime \prime}\right), 75.5\left(\mathrm{C}-5^{\prime \prime}\right), 73.1\left(\mathrm{C}-2^{\prime \prime}\right), 71.8\left(\mathrm{C}-4^{\prime \prime}\right)$.

Hypolaetin 8-O- $\beta$-D-glucuronopyranoside (MVW-5-4-13-5-1, 3), yellow amorphous powder; $[\alpha]_{\mathrm{D}}-7.1^{\circ}$ (c $0.10,50 \% \mathrm{MeOH}) ; \mathrm{Mp}$ decomposed $>300{ }^{\circ} \mathrm{C}$; $\mathrm{IR}(\mathrm{KBr}, v) 3383,1635,1620,1580 \mathrm{~cm}^{-1}$; positive ESI-QTof-MS $m / z 479[\mathrm{M}+\mathrm{H}]^{+} ;{ }^{1} \mathrm{H}-\mathrm{NMR}\left(400 \mathrm{MHz}\right.$, pyridine- $d_{5}$ and $\left.\mathrm{D}_{2} \mathrm{O}, \delta_{\mathrm{H}}\right) 7.78(1 \mathrm{H}, \mathrm{d}, J=2.0$, H-2' $), 7.40\left(1 \mathrm{H}, \mathrm{dd}, J=8.4,2.0, \mathrm{H}^{\prime} 6^{\prime}\right), 6.90\left(1 \mathrm{H}, \mathrm{d}, J=8.4, \mathrm{H}^{\prime} 5^{\prime}\right), 6.48(1 \mathrm{H}, \mathrm{s}, \mathrm{H}-3), 6.06(1 \mathrm{H}, \mathrm{s}, \mathrm{H}-6), 4.51$ $\left(1 \mathrm{H}, \mathrm{d}, J=7.6, \mathrm{H}-1^{\prime \prime}\right), 3.71\left(1 \mathrm{H}, \mathrm{m}, \mathrm{H}-4^{\prime \prime}\right), 3.63\left(2 \mathrm{H}\right.$, overlapped, $\left.\mathrm{H}-2^{\prime \prime}{ }^{\prime \prime} 3^{\prime \prime}\right), 3.49\left(1 \mathrm{H}, \mathrm{d}, J=8.8, \mathrm{H}-5^{\prime \prime}\right)$; ${ }^{13} \mathrm{C}-\mathrm{NMR}\left(100 \mathrm{MHz}\right.$, pyridine- $d_{5}$ and $\left.\mathrm{D}_{2} \mathrm{O}, \delta_{\mathrm{C}}\right) 182.7(\mathrm{C}-4), 173.8\left(\mathrm{C}-6^{\prime \prime}\right), 165.7$ (C-2), $159.8(\mathrm{C}-7), 158.3$ (C-5), $151.2\left(\mathrm{C}-4^{\prime}\right), 150.4(\mathrm{C}-9), 146.9\left(\mathrm{C}-3^{\prime}\right), 130.2(\mathrm{C}-8), 124.1\left(\mathrm{C}-1^{\prime}\right), 120.3\left(\mathrm{C}-6^{\prime}\right), 114.3\left(\mathrm{C}-2^{\prime}, 5^{\prime}\right), 106.1$ $\left(\mathrm{C}-1^{\prime \prime}\right), 102.7(\mathrm{C}-3,10), 99.5(\mathrm{C}-6), 76.7\left(\mathrm{C}-3^{\prime \prime}\right), 75.5\left(\mathrm{C}-5^{\prime \prime}\right), 73.1\left(\mathrm{C}-2^{\prime \prime}\right), 71.8\left(\mathrm{C}-4^{\prime \prime}\right)$.

Herbacetin 8-O- $\beta$-D-glucuronopyranoside (MVW-5-4-13-3-2, 4), yellow amorphous powder; $[\alpha]_{\mathrm{D}}-5.0^{\circ}$ (c $0.10,50 \% \mathrm{MeOH}) ; \mathrm{Mp}$ decomposed $>300{ }^{\circ} \mathrm{C}$; $\mathrm{IR}(\mathrm{KBr}, v) 3380,1633,1622,1579 \mathrm{~cm}^{-1}$; positive ESI-QTof-MS $m / z 479[\mathrm{M}+\mathrm{H}]^{+} ;{ }^{1} \mathrm{H}-\mathrm{NMR}\left(400 \mathrm{MHz}\right.$, pyridine- $d_{5}$ and $\left.\mathrm{D}_{2} \mathrm{O}, \delta_{\mathrm{H}}\right) 8.74(2 \mathrm{H}, \mathrm{d}, J=7.6$, $\left.2^{\prime}, 6^{\prime}\right), 7.31\left(2 \mathrm{H}, \mathrm{d}, J=7.6,3^{\prime}, 5^{\prime}\right), 6.50(1 \mathrm{H}, \mathrm{s}, \mathrm{H}-6), 4.89\left(1 \mathrm{H}, \mathrm{d}, J=6.8, \mathrm{H}-1^{\prime \prime}\right), 4.16\left(1 \mathrm{H}, \mathrm{m}, \mathrm{H}-4^{\prime \prime}\right), 4.05$ $\left(2 \mathrm{H}\right.$, overlapped, $\left.\mathrm{H}-2^{\prime \prime}, 3^{\prime \prime}\right), 3.90\left(1 \mathrm{H}, \mathrm{d}, J=8.0, \mathrm{H}-5^{\prime \prime}\right) ;{ }^{13} \mathrm{C}-\mathrm{NMR}\left(100 \mathrm{MHz}\right.$, pyridine- $d_{5}$ and $\left.\mathrm{D}_{2} \mathrm{O}, \delta_{\mathrm{C}}\right)$ 181.5 (C-4), $171.2\left(\mathrm{C}-6^{\prime \prime}\right), 159.4$ (C-2), 159.2 (C-4'), 156.0 (C-5,7), 147.9 (C-9), 133.0 (C-3), 131.1 (C-2', , $\left.6^{\prime}\right)$, $125.5(\mathrm{C}-8), 120.1\left(\mathrm{C}-1^{\prime}\right), 114.6\left(\mathrm{C}-3^{\prime}, 5^{\prime}\right), 105.7\left(\mathrm{C}-1^{\prime \prime}\right), 102.1(\mathrm{C}-10), 99.1(\mathrm{C}-6), 76.4\left(\mathrm{C}-3^{\prime \prime}\right), 75.7\left(\mathrm{C}-5^{\prime \prime}\right)$, $74.1\left(2^{\prime \prime}\right), 71.5\left(\mathrm{C}-4^{\prime \prime}\right)$. 
Herbacetin 3-O- $\beta$-D-glucopyranosyl-8-O- $\beta$-D-glucuronopyranoside (MVW-5-4-13-3-4, 5), yellow amorphous powder; $[\alpha]_{\mathrm{D}}-5.7^{\circ}(c 0.10,50 \% \mathrm{MeOH})$; Mp decomposed $>300{ }^{\circ} \mathrm{C}$; $\mathrm{IR}(\mathrm{KBr}, v) 3378$, $1632,1625,1583 \mathrm{~cm}^{-1}$; positive ESI-QTof-MS $\mathrm{m} / z 641[\mathrm{M}+\mathrm{H}]^{+} ;{ }^{1} \mathrm{H}-\mathrm{NMR}\left(400 \mathrm{MHz}\right.$, pyridine- $d_{5}$ and $\left.\mathrm{D}_{2} \mathrm{O}, \delta_{\mathrm{H}}\right) 8.76\left(2 \mathrm{H}, \mathrm{d}, J=7.2, \mathrm{H}-2^{\prime}, 6^{\prime}\right), 7.33\left(2 \mathrm{H}, \mathrm{d}, J=7.2,3^{\prime}, 5^{\prime}\right), 6.54(1 \mathrm{H}, \mathrm{s}, \mathrm{H}-6), 5.79(1 \mathrm{H}, \mathrm{d}, J=6.8$, $\left.\mathrm{H}-1^{\prime \prime}\right), 4.92\left(1 \mathrm{H}, \mathrm{d}, J=6.8, \mathrm{H}-1^{\prime \prime \prime}\right), 4.18\left(1 \mathrm{H}, \mathrm{m}, \mathrm{H}-4^{\prime \prime \prime}\right), 4.15\left(1 \mathrm{H}, \mathrm{m}, \mathrm{H}-6^{\prime \prime} \mathrm{a}\right), 3.92-4.10$ (4H, overlapped, $\left.\mathrm{H}-2^{\prime \prime}-5^{\prime \prime}\right), 4.07\left(2 \mathrm{H}\right.$, overlapped, $\left.\mathrm{H}-2^{\prime \prime \prime}, 3^{\prime \prime \prime}\right), 4.00\left(2 \mathrm{H}\right.$, overlapped, $\left.\mathrm{H}-6^{\prime \prime} \mathrm{b}, 5^{\prime \prime \prime}\right) ;{ }^{13} \mathrm{C}-\mathrm{NMR}(100 \mathrm{MHz}$, pyridine- $d_{5}$ and $\left.\mathrm{D}_{2} \mathrm{O}, \delta_{\mathrm{C}}\right) 182.0(\mathrm{C}-4), 171.7\left(\mathrm{C}-6^{\prime \prime \prime}\right), 159.9(\mathrm{C}-2), 159.8\left(\mathrm{C}-4^{\prime}\right), 156.3(\mathrm{C}-5,7), 148.3(\mathrm{C}-9)$, $133.5(\mathrm{C}-3), 131.5\left(\mathrm{C}-2^{\prime}, 6^{\prime}\right), 125.9(\mathrm{C}-8), 120.6\left(\mathrm{C}-1^{\prime}\right), 115.0\left(\mathrm{C}-3^{\prime}, 5^{\prime}\right), 106.1\left(\mathrm{C}-1^{\prime \prime \prime}\right), 102.8\left(\mathrm{C}-1^{\prime \prime}\right), 102.6$ (C-10), 99.5 (C-6), $77.4\left(\mathrm{C}-3^{\prime \prime}\right), 76.7\left(\mathrm{C}-3^{\prime \prime \prime}\right), 76.1\left(\mathrm{C}-5^{\prime \prime \prime}\right), 76.0\left(\mathrm{C}-5^{\prime \prime}\right), 74.5\left(\mathrm{C}-2^{\prime \prime}, 2^{\prime \prime \prime}\right), 71.9\left(\mathrm{C}-4^{\prime \prime \prime}\right), 69.8$ $\left(\mathrm{C}-4^{\prime \prime}\right), 60.9\left(\mathrm{C}-6^{\prime \prime}\right)$.

Isoscutellarein 7-O- $\beta$-D-glucopyranoside (MVW-5-4-13-4-8, 6), yellow amorphous powder; $[\alpha]_{\mathrm{D}}-19.2^{\circ}$ (c $0.10,50 \% \mathrm{MeOH})$; Mp decomposed $>300{ }^{\circ} \mathrm{C}$; IR $(\mathrm{KBr}, v) 3477,1616,1579 \mathrm{~cm}^{-1}$; positive ESI-QTof-MS $m / z 449[\mathrm{M}+\mathrm{H}]^{+} ;{ }^{1} \mathrm{H}-\mathrm{NMR}\left(400 \mathrm{MHz}\right.$, pyridine- $\left.d_{5}, \delta_{\mathrm{H}}\right) 8.40\left(2 \mathrm{H}, \mathrm{d}, J=8.0, \mathrm{H}-2^{\prime}, 6^{\prime}\right), 7.48(2 \mathrm{H}, \mathrm{d}, J=8.0$, $\left.\mathrm{H}-3^{\prime}, 5^{\prime}\right), 6.91(1 \mathrm{H}, \mathrm{s}, \mathrm{H}-6), 6.71(1 \mathrm{H}, \mathrm{s}, \mathrm{H}-3), 5.56\left(1 \mathrm{H}, \mathrm{d}, J=7.2, \mathrm{H}-1^{\prime \prime}\right), 4.21(1 \mathrm{H}, \mathrm{dd}, J=12.0,2.0$, $\left.\mathrm{H}-6^{\prime \prime} \mathrm{a}\right), 3.85-4.10\left(4 \mathrm{H}\right.$, overlapped, H-2 $\left.{ }^{\prime \prime}-5^{\prime \prime}\right), 3.68\left(1 \mathrm{H}, \mathrm{dd}, J=12.0,5.2, \mathrm{H}-6^{\prime \prime} \mathrm{b}\right) ;{ }^{13} \mathrm{C}-\mathrm{NMR}(100 \mathrm{MHz}$, pyridine- $\left.d_{5}, \delta_{\mathrm{C}}\right) 182.0(\mathrm{C}-4), 163.8(\mathrm{C}-2), 161.9\left(\mathrm{C}-4^{\prime}\right), 156.2(\mathrm{C}-7), 156.0(\mathrm{C}-5), 144.1(\mathrm{C}-9), 129.9\left(\mathrm{C}-2^{\prime}, 6^{\prime}\right)$, $125.6(\mathrm{C}-8), 121.0\left(\mathrm{C}-1^{\prime}\right), 115.8\left(\mathrm{C}-3^{\prime}, 5^{\prime}\right), 104.7(\mathrm{C}-10), 102.5(\mathrm{C}-3), 101.2\left(\mathrm{C}-1^{\prime \prime}\right), 98.7(\mathrm{C}-6), 77.2\left(\mathrm{C}-5^{\prime \prime}\right)$, $75.8\left(\mathrm{C}-3^{\prime \prime}\right), 73.1\left(\mathrm{C}-2^{\prime \prime}\right), 69.6\left(\mathrm{C}-4^{\prime \prime}\right), 60.9\left(\mathrm{C}-6^{\prime \prime}\right)$.

\subsection{Zebrafish Care and Maintenance}

Adult zebrafish were maintained in a zebrafish system $S$ type $(1500[\mathrm{~W}] \times 400[\mathrm{D}] \times 2050[\mathrm{H}]$ $\mathrm{mm}$ ) (Daejeon, Korea) and a $14 \mathrm{~h}$ light $/ 10 \mathrm{~h}$ dark cycle at $28.5^{\circ} \mathrm{C}$. Two pairs of adult zebrafish were placed in a spawning box overnight to obtain zebrafish larvae. The zebrafish spawned during a $30 \mathrm{~min}$ period of light. Zebrafish embryos were then collected at $3 \mathrm{~h}$ post-fertilization for incubation, and were maintained in a $0.03 \%$ sea salt solution for a $14 / 10 \mathrm{~h}$, light/dark photocycle in an incubator at $28.5^{\circ} \mathrm{C}$. The fish were cared for in accordance with standard zebrafish protocols approved by the Animal Care and Use Committee of Kyung Hee University (KHUASP[SE]-15-10).

\subsection{Evaluation of the Toxicity in Zebrafish Embryo}

Twenty zebrafish embryos were used treatment for toxic test. Exposure of fish embryos was performed for $96 \mathrm{~h}$ as outlined in the OECD TG 236 for the Fish Embryo Acute Toxicity (FET) Test [40]. 31 treatments were used: normal, EtOAc, $n-\mathrm{BuOH}$, and aqueous Frs at the concentration 25, 50, 75, 100, 150, 200, 300, 400, 500 and $600 \mu \mathrm{g} / \mathrm{mL}$, respectively. The zebrafish were observed under the microscope after $96 \mathrm{~h}$ treatment and dead zebrafish were recorded. $\mathrm{LC}_{50}$ values were calculated by non-linear regression using GraphPad Prism version 5.01 software.

\subsection{Evaluation of Recovery Efficacy for AX-Induced PI Damage in Zebrafish Larvae}

The zebrafish larvae were divided into the normal group, AX-induced group (control group), and AX-induced groups treated with the different Frs and Coms 1-6. Wild-type zebrafish larvae (5 dpf) were placed into 24-well plates. The larvae were exposed to $600 \mu \mathrm{M} \mathrm{AX}$ for $3 \mathrm{~h}$ to induce PI damage. The AX-induced larvae were treated with $10 \mu \mathrm{g} / \mathrm{mL}$ Frs or $0.1 \mu \mathrm{M}$ Coms for $12 \mathrm{~h}$ so that the recovery efficacy of the Frs and Coms could be determined. Then, the larvae were stained for $30 \mathrm{~min}$ with $40 \mu \mathrm{M}$ 2-NBDG and rinsed with a $0.03 \%$ sea salt solution for $20 \mathrm{~min}$. After the staining, the PIs were confirmed by fluorescence microscope and analyzed with Focus Lite software.

\subsection{Action of DZ on AX-induced Diabetic Zebrafish}

Wild-type zebrafish larvae ( $5 \mathrm{dpf}$ ) were placed in 24 -well plates (10 zebrafish per well). The larvae were divided into the following 14 groups: normal, normal treated with $\mathrm{DZ}$ or $\mathrm{AX}$, and $\mathrm{AX}$-induced diabetic treated with DZ, GLM, GLM + DZ, Com 1, Com 1 + DZ, Com 3, Com 3 + DZ, Com 4, Com 
$4+\mathrm{DZ}$, Com 6, and Com $6+\mathrm{DZ}$. The Coms were applied at $0.1 \mu \mathrm{M}$ each, and DZ was applied at $25 \mu \mathrm{M}$. The zebrafish larvae were treated with $600 \mu \mathrm{M}$ AX for $3 \mathrm{~h}$, after which the solution was rinsed with a $0.03 \%$ sea salt solution. The AX-induced zebrafish larvae were treated with the respective Coms and/or treatments for $12 \mathrm{~h}$. Following treatment, the zebrafish larvae were stained with $40 \mu \mathrm{M}$ 2-NBDG for $30 \mathrm{~min}$ and rinsed with a $0.03 \%$ sea salt solution for $20 \mathrm{~min}$. After the staining, PI images were captured by fluorescence microscopy and analyzed with Focus Lite software.

\subsection{Statistical Analysis}

Statistical analysis was performed with GraphPad Prism (version 5). Data are expressed as the mean \pm standard error of the mean (SEM) for three replicates. Significance was determined with repeated one-way ANOVA followed by Tukey's test. The probability level for statistical significance was $p<0.05$.

\subsection{DPPH RS Activity}

According to the method of Brand-Williams [41], DPPH RS activity was measured. First, $100 \mu \mathrm{M}$ DPPH• was dissolved in 70\% aqueous methanol. Then, Coms 1-6 $(0.1 \mathrm{~mL})$ were added to $2.9 \mathrm{~mL}$ of the methanolic DPPH• solution. The mixture was shaken vigorously and allowed to stand at $23{ }^{\circ} \mathrm{C}$ in the dark for $30 \mathrm{~min}$. The decrease in absorbance of the resulting solution was monitored at $517 \mathrm{~nm}$ for $30 \mathrm{~min}$. The control consisted of $0.1 \mathrm{~mL}$ of $70 \%$ aqueous methanol and $2.9 \mathrm{~mL}$ of DPPH• solution. Positive controls (the natural anti-oxidant quercetin and the synthetic anti-oxidant BHA [butylated hydroxyl anisole]) were also subjected to the same procedure for comparison. The results were confirmed in triplicate analyses, and the DPPH RS activity was calculated with the following equation:

$$
\text { RS activity }(\%)=\left(\text { A } 517_{\text {control }}-\mathrm{A} 517_{\text {sample }}\right) / \mathrm{A} 517_{\text {control }} \times 100
$$

The EC50 was determined as the concentration required to obtain a $50 \%$ RS effect.

\subsection{ABTS RS Activity}

The ABTS RS assay was carried out according to a published protocol [42]. A radical initiator, $1.0 \mathrm{mM}$ AAPH, was added to $2.5 \mathrm{mM}$ ABTS in phosphate-buffered saline (PBS; pH 7.4; $0.1 \mathrm{M}$ $\mathrm{K}_{2} \mathrm{HPO}_{4} / \mathrm{KH}_{2} \mathrm{PO}_{4}$ buffer; $150 \mathrm{mM} \mathrm{NaCl}$ ). The mixed solution was heated in a water bath at $68{ }^{\circ} \mathrm{C}$. The resulting blue-green ABTS radical solution was adjusted to an absorbance of $0.650 \pm 0.020$ at $734 \mathrm{~nm}$ with additional PBS. Then, $20 \mu \mathrm{L}$ of the sample was added to $980 \mu \mathrm{L}$ of the ABTS radical solution. The mixture was incubated in a $37^{\circ} \mathrm{C}$ water bath under restricted light for $10 \mathrm{~min}$. A control ( $20 \mu \mathrm{L}$ of $70 \%$ methanol and $980 \mu \mathrm{L}$ of the ABTS radical solution) was run with each series of samples. Positive controls (the natural anti-oxidant quercetin and the synthetic anti-oxidant BHA) were also subjected to the same procedure for comparison. The reduction of absorbance at $734 \mathrm{~nm}$ was measured 10 min later. The ABTS radical, exhibiting a characteristic blue-green color in its odd-electron state, loses color when its unpaired electron is paired with an electron from an anti-oxidant. The results were confirmed in triplicate analyses, and the ABTS RS activity was calculated with the following equation:

$$
\text { RS activity }(\%)=\left(\text { A734 } 4_{\text {control }}-\mathrm{A} 734_{\text {sample }}\right) / \mathrm{A} 734_{\text {control }} \times 100
$$

The EC50 was determined as the concentration required to obtain a 50\% RS effect.

\subsection{Oxygen Radical Absorbance Capacity (ORAC) Assay}

The ABTS RS assay was carried out according to a published protocol [43]. Appropriately diluted samples and the standards with $150 \mu \mathrm{L}$ of $81.6 \mathrm{nM}$ fluorescein solution were added to a 96-well plate and incubated at $37^{\circ} \mathrm{C}$ for 10 min with 3 min of shaking. $25 \mu \mathrm{L}$ of $153 \mathrm{mM}$ AAPH solution was added and fluorescence was then detected every minute for 90 min using a microplate reader (Infinite M200, 
Tecan Austria GmbH, Grödig, Austria) with $485 \mathrm{~nm}$ excitation and $520 \mathrm{~nm}$ emission wavelengths. The ORAC values were calculated according to the method of Cao et al [44], and expressed as a Trolox equivalent ( $\mu \mathrm{mol} \mathrm{TE} / \mu \mathrm{mol})$.

\subsection{Superoxide Scavenging Activity}

Superoxide RS activity was measured based on the capacity of the Coms to inhibit the photochemical production of superoxide in the riboflavin-light-NBT system. The reaction mixture for the measurement of superoxide RS activity contained $0.02 \mathrm{mM}$ riboflavin, $3 \mathrm{mM}$ methionine, and $0.18 \mathrm{mM}$ NBT in $50 \mathrm{mM}$ potassium phosphate buffer (pH 7.8). Samples in DMSO (10 $\mu \mathrm{L})$ and $150 \mu \mathrm{L}$ of the reaction mixture were dispensed into a 96-well plate. The reaction was started with fluorescent illumination (1000 lux) and allowed to proceed for $6 \mathrm{~min}$ at room temperature. The absorbance at $530 \mathrm{~nm}$ was measured on a microplate reader (Molecular Devices, Sunnyvale, CA, USA). The natural anti-oxidant quercetin and the synthetic anti-oxidant BHA were used as positive controls. The results were confirmed in triplicate analyses, and the superoxide scavenging activity was calculated with the following equation:

$$
\text { RS activity }(\%)=\left(\mathrm{A} 530_{\text {control }}-\mathrm{A} 530_{\text {sample }}\right) / \mathrm{A} 530_{\text {control }} \times 100
$$

The EC50 was determined as the concentration required to obtain a 50\% RS effect.

Supplementary Materials: ${ }^{1} \mathrm{H}$ and ${ }^{13} \mathrm{C}-\mathrm{NMR}$, gHSQC, gHMBC, and ESI-QTof-MS spectra data of compound 1.

Acknowledgments: This work was supported by the Korea Institute of Planning and Evaluation for Technology in food, agriculture, forestry, and fisheries (317071-03-1-SB020).

Author Contributions: J.-H.K. and N.-I.B. conceived and designed the experiments; Y.H.N. and T.H.K. carried out the biological assay; J.-H.K. and S.-W.J. isolated the compounds; J.-H.K. elucidated the structures; J.-H.K., H.-G.K. and Y.-G.L. contributed to the plant materials preparation; J.-H.K. performed the NMRs; and J.-H.K. and N.-I.B. wrote the paper and managed the research project. All authors read and approved the final manuscript.

Conflicts of Interest: The authors declare no conflict of interest.

\section{References}

1. Arkhtar, K.; Shah, S.W.A.; Shak, A.A.; Haleem, S.K.; Sultana, N. Pharmacological effect of Rubus ulmifolius Schott as antihyperglycemic and antihyperlipidemic on streptozotocin (STZ)-induced albino mice. Appl. Biol. Chem. 2017, 60, 411-418. [CrossRef]

2. Rhodes, C.J. Type 2 diabetes-a matter of $\beta$-cell life and death? Science 2005, 307, 380-384. [CrossRef] [PubMed]

3. Rorsman, P.; Renstroöm, E. Insulin granule dynamics in pancreatic beta cells. Diabetologia 2003, 46, $1029-1045$. [CrossRef] [PubMed]

4. Rhodes, C.J.; White, M.F. Molecular insights into insulin action and secretion. Eur. J. Clin. Invest. 2002, 32, 3-13. [CrossRef] [PubMed]

5. Liu, R.H. Potential synergy of phytochemicals in cancer prevention: Mechanism of action. J. Nutr. 2004, 134, 3479S-3485S. [CrossRef] [PubMed]

6. Mollet, B.; Rowland, I. Functional foods: At the frontier between food and pharma. Curr. Opin. Iotechnol. 2002, 13, 483-485. [CrossRef]

7. Roberfroid, M.B. A European consensus of scientific concepts of functional foods. Nutrition 2000, 16, 689-691. [CrossRef]

8. Oh, Y.S.; Jun, H.S. Role of bioactive food components in diabetes prevention: Effects on beta-cell function and preservation. Nutr. Metab. Insights 2014, 7, 51. [CrossRef] [PubMed]

9. Hollman, P.C.H.; Katan, M.B. Dietary Flavonoids: Intake, Health Effects and Bioavailability. Food Chem. Toxicol. 1999, 37, 937-942. [CrossRef]

10. Ames, B.N.; Shigenaga, M.K.; Hagen, T.M. Oxidants, antioxidants, and the degenerative diseases of aging. Proceed. Natl. Acad. 1993, 90, 7915-7922. [CrossRef] 
11. Odontuya, G.; Enkhmaa, G.; Batbayar, N.; Naran, R.; Inngjerdingen, K.T.; Michaelsen, T.E.; Paulsen, B.S. Pharmacological activities of a mongolian medicinal plant, Malva mohileviensis Down. Eur. J. Med. Plant 2012, 2, 230-241. [CrossRef]

12. Gonda, R.; Tomoda, M.; Shimizu, N.; Kanari, M. Characterization of an acidic polysaccharide from the seeds of Malva verticillata stimulating the phagocytic activity of cells of the RES1. Planta Med. 1990, 56, 73-76. [CrossRef] [PubMed]

13. Ko, J.H.; Cho, S.M.; Joo, S.W.; Kim, H.G.; Lee, Y.G.; Kang, S.C.; Baek, N.I. Glycosyl glycerides from the aerial parts of Malva verticillata and their chemopreventive effects. Bioor. Chem. 2018. In press. [CrossRef]

14. Ko, J.H.; Castaneda, R.; Joo, S.W.; Kim, H.G.; Lee, Y.G.; Lee, Y.H.; Kang, T.H.; Baek, N.I. Glycerides isolated from the aerial parts of Malva verticillata cause immunomodulation effects via splenocyte function and NK anti-tumor activity. Food Sci. Biotechnol. 2018, 1-8. [CrossRef]

15. Sangwan, V.; Tomar, S.K.; Ali, B.; Singh, R.R.; Singh, A.K. Hypoglycaemic effect of galactooligosaccharides in alloxan-induced diabetic rats. J. Dairy Res. 2015, 82, 70-77. [CrossRef] [PubMed]

16. Yamashita, K.; Kawai, K.; Itakura, M. Effects of fructo-oligosaccharides on blood glucose and serum lipids in diabetic subjects. Nutr. Res. 1984, 4, 961-966. [CrossRef]

17. Casirola, D.M.; Ferraris, R.P. $\alpha$-Glucosidase inhibitors prevent diet-induced increases in intestinal sugar transport in diabetic mice. Metab. Clin. Exp. 2006, 55, 832-841. [CrossRef] [PubMed]

18. Agheli, N.; Kabir, M.; Berni-Canani, S.; Petitjean, E.; Boussairi, A.; Luo, J.; Bornet, F.; Salma, G.; Rizkalla, S.W. Plasma lipids and fatty acid synthase activity are regulated by short-chain fructo-oligosaccharides in sucrose-fed insulin-resistant rats. J. Nutr. 1998, 128, 1283-1288. [CrossRef] [PubMed]

19. Sun, H.; Dong, T.; Zhang, A.; Yang, J.; Yan, G.; Sakurai, T.; Wu, X.; Han, Y.; Wang, X. Pharmacokinetics of hesperetin and naringenin in the Zhi ZhuWan, a traditional Chinese medicinal formulae, and its pharmacodynamics study. Phytother. Res. 2013, 27, 1345-1351. [CrossRef] [PubMed]

20. Nijveldt, R.J.; Van Nood, E.L.S.; Van Hoorn, D.E.; Boelens, P.G.; Van Norren, K.; Van Leeuwen, P.A. Flavonoids: A review of probable mechanisms of action and potential applications. Am. J. Clin. Nutr. 2001, 74, 418-425. [CrossRef] [PubMed]

21. Kataja-Tuomola, M.K.; Kontto, J.P.; Männistö, S.; Albanes, D.; Virtamo, J. Intake of antioxidants and risk of type 2 diabetes in a cohort of male smokers. Eur. J. Clin. Nutr. 2011, 65, 590-597. [CrossRef] [PubMed]

22. Hodgson, J.M. Tea flavonoids and cardiovascular disease. Asia Pac. J. Clin. Nutr. 2008, 17, 288-290. [PubMed]

23. Song, Y.; Manson, J.E.; Buring, J.E.; Sesso, H.D.; Liu, S. Associations of dietary flavonoids with risk of type 2 diabetes, and markers of insulin resistance and systemic inflammation in women: a prospective study and cross-sectional analysis. J. Am. Coll. Nutr. 2005, 24, 376-384. [CrossRef] [PubMed]

24. Liu, Y.J.; Zhan, J.; Liu, X.L.; Wang, Y.; Ji, J.; He, Q.Q. Dietary flavonoids intake and risk of type 2 diabetes: A meta-analysis of prospective cohort studies. Clin. Nutr. 2014, 33, 59-63. [CrossRef] [PubMed]

25. Choi, S.A.; Lee, J.E.; Kyung, M.J.; Youn, J.H.; Oh, J.B.; Whang, W.K. Anti-diabetic functional food with wasted litchi seed and standard of quality control. Appl. Biol. Chem. 2017, 60, 197-204. [CrossRef]

26. Billeter, M.; Meier, B.; Sticher, O. 8-Hydroxyflavonoid glucuronides from Malva sylvestris. Phytochemistry 1991, 30, 987-990. [CrossRef]

27. Wolbiś, M. Flavonol glycosides from Sedum album. Phytochemistry 1989, 28, 2187-2189. [CrossRef]

28. Sikorska, M.; Matławska, I. 8-Hydroxyflavonoid glucuronides of Malope trifida. Acta Physiol. Plant. 2004, 26, 291-297. [CrossRef]

29. Iida, N.; Inatomi, Y.; Murata, H.; Inada, A.; Murata, J.; Lang, F.A.; Matsuura, N.; Nakanishi, T. A new flavone xyloside and two new flavan-3-ol glucosides from Juniperus communis var. depressa. Chem. Biodivers. 2007, 4, 32-42. [CrossRef] [PubMed]

30. Nam, Y.H.; Hong, B.N.; Rodriguez, I.; Ji, M.G.; Kim, K.; Kim, U.J.; Kang, T.H. Synergistic potentials of coffee on injured pancreatic islets and insulin action via $\mathrm{K}_{\mathrm{ATP}}$ channel blocking in zebrafish. J. Agric. Food Chem. 2015, 63, 5612-5621. [CrossRef] [PubMed]

31. Nam, Y.H.; Le, H.T.; Rodriguez, I.; Kim, E.Y.; Kim, K.; Jeong, S.Y.; Woo, S.H.; Lee, Y.R.; Castañeda, R.; Hong, J.; et al. Enhanced antidiabetic efficacy and safety of compound $\mathrm{K} / \beta$-cyclodextrin inclusion complex in zebrafish. J. Ginseng Res. 2017, 41, 103-112. [CrossRef] [PubMed]

32. Phadatare, P.D.; Chandrashekhar, V.M. Influence of esomeprazole on hypoglycemic activity of oral antidiabetic agents in rats and rabbits. Mol. Cell. Biochem. 2011, 354, 135-140. [CrossRef] [PubMed] 
33. Yoshioka, K.; Saito, M.; Oh, K.B.; Nemoto, Y.; Matsuoka, H.; Natsume, M.; Abe, H. Intracellular fate of 2-NBDG, a fluorescent probe for glucose uptake activity, in Escherichia coli cells. Biosci. Biotechnol. Biochem. 1996, 60, 1899-1901. [CrossRef] [PubMed]

34. Lee, J.; Jung, D.W.; Kim, W.H.; Um, J.I.; Yim, S.H.; Oh, W.K.; Williams, D.R. Development of a highly visual, simple, and rapid test for the discovery of novel insulin mimetics in living vertebrates. ACS Chem. Boil. 2013, 8, 1803-1814. [CrossRef] [PubMed]

35. Lee, Y.A.; Cho, E.J.; Tanaka, T.; Yokozawa, T. Inhibitory activities of proanthocyanidins from persimmon against oxidative stress and digestive enzymes related to diabetes. J. Nutr. Sci. Vitaminol. 2007, 53, 287-292. [CrossRef] [PubMed]

36. Wang, H.; Du, Y.J.; Song, H.C. $\alpha$-Glucosidase and $\alpha$-amylase inhibitory activities of guava leaves. Food Chem. 2010, 123, 6-13. [CrossRef]

37. Liu, C.; Chan, C.B.; Ye, K. 7,8-dihydroxyflavone, a small molecular TrkB agonist, is useful for treating various BDNF-implicated human disorders. Transl. Neurodegener. 2016, 5, 2-9. [CrossRef] [PubMed]

38. Hirano, R.; Sasamoto, W.; Matsumoto, A.; Itakura, H.; Igarashi, O.; Kondo, K. Antioxidant ability of various flavonoids against DPPH radicals and LDL oxidation. J. Nutr. Sci. Vitaminol. 2001, 47, 357-362. [CrossRef] [PubMed]

39. Lu, Y.; Foo, L.Y. Antioxidant and radical scavenging activities of polyphenols from apple pomace. Food Chem. 2000, 68, 81-85. [CrossRef]

40. Organisation for Economic Co-operation and Development (OECD). Test Guideline 236: Guideline for Testing of Chemicals, Fish Embryo Acute toxicity (Fet) Test. In OECD Guidelines for the Testing of Chemicals, Section 2; OECD Publishing: Paris, France, 2013; pp. 1-22.

41. Brand-Williams, W.; Cuvelier, M.E.; Berset, C.L.W.T. Use of a free radical method to evaluate antioxidant activity. LWT-Food Sci. Technol. 1995, 28, 25-30. [CrossRef]

42. Chen, D.; Shi, J.; Hu, X. Enhancement of polyphenol content and antioxidant capacity of oat (Avena nuda L.) bran by cellulase treatment. Appl. Biol. Chem. 2016, 59, 397-403. [CrossRef]

43. Huang, D.; Ou, B.; Hampsch-Woodill, M.; Flanagan, J.A.; Prior, R.L. High-throughput assay of oxygen radical absorbance capacity (ORAC) using a multichannel liquid handling system coupled with a microplate fluorescence reader in 96-well format. J. Agr. Food Chem. 2002, 50, 4437-4444. [CrossRef]

44. Cao, G.; Alessio, H.M.; Cutler, R.G. Oxygen-radical absorbance capacity assay for antioxidants. Free Radical Biol. Med. 1993, 14, 303-311. [CrossRef]

Sample Availability: Sample of the compound 1 is available from the authors.

(C) 2018 by the authors. Licensee MDPI, Basel, Switzerland. This article is an open access article distributed under the terms and conditions of the Creative Commons Attribution (CC BY) license (http:/ / creativecommons.org/licenses/by/4.0/). 